stations each having a capacity greater than 100,000 $\mathrm{kw}$. The capacity has increased more rapidly than the output owing to the necessity of keeping a large reserve of power to meet sudden fluctuations in the consumption. In Paris, for example, the rate of consumption varies between $50,000 \mathrm{kw}$. at 3 a.m. and $340,000 \mathrm{kw}$. at 5 p.m. The rate of consumption of hydro-electric power is now greater than that of thermal power. It is noteworthy that the total length of the distributing lines is increasing more rapidly than the consumption of power. This is due to the increasing number of small consumers and to the fact that, as the supply service is extended to the more remote regions, longer lines are needed to reach new users. At present it is necessary to lay 46 metres of low tension line, on the average, to supply each new consumer, whereas in 1923 the length of line required was 13 metres. The large industries consume 7,100 million $\mathrm{kwh}$. per annum and electrochemistry and electrometallurgy together take 2,200. Lighting and domestic supply take 1,800 , small industries 1,000 and traction 900. There are now 35,369 communes supplied with electricity, and only about 2,600 not so provided.

\section{Protection against Gas Attacks}

THE Socialist Medical Association has issued a booklet entitled "Gas Attacks: Is there any Protection?" (London: Lawrence and Wishart, Ltd. $6 d$.$) . It is maintained that air-raiders are certain$ to penetrate our defences, and will not hesitate to employ a combination of high explosives, fire and gas in their attacks, against which the only efficient protections are respirators and gas- and bomb-proof self-contained dug-outs. The booklet issued by the Home Office, "Anti-Gas Precautions and First Aid for Air-Raid Casualties", is criticized, and is considered to give an incorrect impression of the dangers of war gases and possibilities of protection, and that the defences proposed, even if they could be generally adopted, would be inadequate. Dr. Sommerville Hastings contributes an introduction, the nature of the gases employed and their effects are described, and the available means of protection and the treatment of gas casualties are discussed.

\section{Bulletin of the Metchnikoff Institute of the Ukraine}

The Metchnikoff Institute of the Ukraine has commenced the issue of a monthly bulletin (Bulletin de l'Institut Metchnikoff) devoted in the main to bacteriological and immunological papers from the Institute, written in French, English and German. In an editorial note to the first number (April 1936), it is remarked that until 1917 bacteriology had made slow progress in Russia, but that since that time many new institutes have been established and the active roll of bacteriologists and epidemiological experts has very greatly expanded. The nineteen extremely brief papers published in the first number are written in summary fashion without bibliographies, but any efforts that facilitate the introduction of Russian work to non-Russian readers are to be heartily welcomed.

\section{The Aquarist and Pond-Keeper}

The Aquarist and Pond-Keeper, incorporating the Reptilian Review, in the March-April number, 1936, has various improvements, including a new cover design. Specially striking is a collection of photographs occupying two pages, which with the illustrations to the article on reptile hunting in Britain by A. E. H., depict the whole of our native species of reptiles and batrachians. Mr. E. Bridgstock-Choat, honorary curator of the Erith Museum, contributes an article entitled "The Pond Hunter", which will be continued, and papers from various other workers deal with fishes, fish-breeding, ponds and water gardening and various allied subjects.

\section{Official Statistics}

Atrention may be directed to the publication of the Guide to Current Official Statistics for 1935 (London: H.M. Stationery Office. Price 1s.). The arrangement is the same as in previous years. The greater part of the volume is occupied by an alpha. betical range of subjects with reference to the appropriate publication. This is followed by a list of publications arranged under departments. The volume is invaluable for quick reference, and reveals the great range of matters on which statistical and other official information is available.

\section{Post-graduate Medical Research}

The Medical Research Council has decided to institute a series of studentships and fellowships to encourage young British medical graduates towards becoming investigators in those branches of medical science which are concerned directly with disease as it occurs in human beings. Six post-graduate studentships are therefore offered for medical graduates who have already held house appointments and are strongly inclined to a career in clinical science or experimental pathology. Each selected student will receive an inclusive grant at the rate of $£ 200$ per annum, during a period not exceeding twelve months, while undertaking approved courses of study in Great Britain such as may be regarded as best calculated to advance the student's training in methods of research. Four research fellowships are also offered for candidates of similar qualifica. tions who have already had some experience in research methods. Each fellowship will be tenable for one year at the value of $£ 250$ per annum, and will be renewable in approved instances at the rate of $£ 300$ per annum for a second year. Further information can be obtained from the Secretary, Medical Research Council, 38 Old Queen Street, London, S.W.1.

\section{Fireball over Yorkshire}

The occurrence on August 18 at about $22^{\mathrm{h}} 23^{\mathrm{m}}$ (Summer Time) of a brilliant object, evidently a fireball or particularly bright meteor, has been referred to by several correspondents in the Yorkshire Post. The accurate observation of the apparent path of a meteor requires a trained observer, and it is to be expected that accounts supplied by casual eye- 